Article

\title{
Trust at Work: A Study on Faith and Trust of Protestant Entrepreneurs in China
}

\author{
Joy K. C. Tong ${ }^{1, *}$ and Fenggang Yang ${ }^{2}$ \\ 1 Department of Sociology and Anthropology, Wheaton College, 501 College Ave, Wheaton, IL 60187, USA \\ 2 Department of Sociology, Purdue University, 700 W. State Street, West Lafayette, IN 47907-2059, USA; \\ fyang@purdue.edu \\ * Correspondence: joy.tong@wheaton.edu or joytkc@gmail.com
}

Academic Editor: Mark G. Toulouse

Received: 20 September 2016; Accepted: 6 December 2016; Published: 20 December 2016

\begin{abstract}
There is much talk about the trust crisis in China and the possible role of religion in rebuilding China's moral order. This study is an attempt to examine religion's impact on the emerging market economy in China, focusing on trust in business relations that might be generated by the Christian faith. Based on 43 in-depth interviews with Christian entrepreneurs in China, our study shows that the majority of our respondents tend to be: (1) more willing to be trustworthy after becoming Christians; (2) trusting people who share their faith more than others; (3) perceiving religious persons, regardless of what that religion is, as more trustworthy than the non-religious. Our study shows that religiosity is used by many Christian entrepreneurs as a category to guide their decision-making and that it is significant in stimulating and maintaining trust in and from others.
\end{abstract}

Keywords: Christianity; China; trust; entrepreneurs

\section{Introduction}

There is much talk about the moral and spiritual crisis in China today, from President Xi Jinping, who was reported to be troubled by what he sees as "the country's moral decline and obsession with money" [1], to the over $80 \%$ of respondents of an online survey by China's Xinhua News Agency in 2011 [2], who believed that popular trust in government and judicial affairs is in "urgent need of improvement." China's market reforms have made it from one of the world's most backward economies to its most dynamic economy. However, alongside rapid economic development, the culture of corruption and exploitation has become a fact of life. It is no wonder that the 2013 Blue Book of Social Mentality revealed that trust among people in China dipped to a record low with less than half of respondents feeling that "most people can be trusted" while only about $30 \%$ trusted strangers [3].

Many scholars have discussed the vital importance of trust to civil society, democracy, and economic development. In a market economy, trust in business relations (supplier/customer, employer/employee, superior/subordinate, and co-worker relations) increases production efficiency and reduces transaction cost [4-7]. Trust is also associated with an increase in economic growth and is an indicator for economic success [8].

Given the importance of trust, the pressing question would then be: How is trust in other persons and institutions established, maintained, or restored? The question requires complex and multi-leveled answers. However, there have been voices, including those from top leaders, such as the abovementioned President $\mathrm{X} i$, advocating China's adoption of religions as one possible source of reconstructing a new morality in its modernization efforts. Given that Protestant Christianity is the fastest growing religion in China, there are increasing numbers of people who argue that it could play a role in rebuilding China's moral order [9-13]. Significantly, at the same time, empirical studies on Protestant Christianity in China $[14,15]$ show that there emerged a new group of "boss Christians" in China. Unlike the 
stereotyped understanding of Chinese Christians as old, female, and lowly-educated peasants, boss Christians are male entrepreneurs who are more educated and adept at integrating business and Christian values. Studies $[12,16,17]$ demonstrate that Christian-owned corporations in China display an abiding belief in Christian ethics, such as integrity, which contribute to workplace practices that are more rational, moral and legal. There was a recent report in The Telegraph on 28 November 2013, entitled "Restaurant confronts China's moral crisis with free food," which reports a 51-year-old Chinese entrepreneur from Fuzhou, Liu Pengfei, who opened his "Good One" buffet in China in what he said was "a bid to rescue a long-lost sense of trust in Chinese society" [18]. By giving customers the choice as to how much they pay—or if they pay at all, Liu, a Christian, hopes that, "When I trust them-the customers-they will trust me and they will begin to love others." Liu's story is not a typical case of faith-business integration. Nevertheless, it illustrates the enormous power of faith in not only motivating people to be trustworthy but also in believers' attempt to influence others to behave similarly.

Through a qualitative study of 43 Christian entrepreneurs in China, this article seeks to examine Christianity's influence on trust. We intend to answer the following questions: Do Christian entrepreneurs' faiths help them re-establish trust that is widely missing in society? If yes, what aspects of religion lead to trust? For example, is it participation in collective rituals [19], adherence to certain beliefs and ethical norms [20], or the belief in a powerful, active, conscious, morally concerned god [21]?

The rest of the paper is organized as follows. We first describe the research method and profile of respondents. We then present the findings of our study from four aspects: (1) how faith affects Christian entrepreneurs' trust in employees; (2) how faith affects their trust in clients and suppliers; (3) how they earn trust from employees and clients; and (4) the reasons for trust. We will then provide our conclusion.

\section{A Brief Review of Trust and Religion}

\subsection{Trust and Religion in General}

Existing empirical studies on the relationship between religion and trust have yielded mixed results. Niclas Berggren and Christian Bjørnskov [22] in their article provide a comprehensive summary of the findings: On the positive side, since all major religions call for behaving well toward others, they have been recognized as significant to stimulate social trust [23]. Studies also show that participation in voluntary association, including religious communities, generates and maintains trust [24-26]. Further, religions often prohibit socially destructive behavior through social or divine enforcement mechanisms [27]. To the extent that people believe that religious persons are regulated by stricter moral demands, such persons are probably viewed as more trustworthy, which may in turn induce trust.

On the other hand, there are studies that show the negative religion-trust effect. Studies show that believers might have less trust in others who are not subjected to the same moral teachings and their trust is mostly restricted to their own group $[5,26,28]$.

\subsection{Trust and Religion in China}

In comparing world religions, Max Weber argues that Confucianism and Daoism have promoted a "particularistic trust" in Chinese societies. Such trust is rooted in the "community of blood" and rested upon personal, familial and semi-familial relationships [29]. It trusts no one except people with whom one has personal relations. For Weber, such trust is in contrast to the universalistic trust, which was built on the "superior community of faith" such as the Puritan sects in the West, and was the foundation for capitalistic enterprises to emerge in Western Europe. Along the same line, political scientist Francis Fukuyama [5] asserts that Confucianism is a reason for the low trust in (overseas) Chinese businesses. Redding [30] also argues that one of the characteristics of Chinese family businesses is that people outside the family are extremely distrusted. These studies seem to 
have altogether suggested that Chinese culture is not conducive to the establishment and maintenance of a kind of social or universal trust.

It will then be natural to ask, what about Christianity, which has a more recent history in China? Does Christianity stimulate or discourage social trust among its Chinese adherents? There have been very few research projects exploring this issue. In his study of Catholics, Richard Madsen shows that in surviving severe political repression, the village-centered Catholics have focused more on hierarchical relationships of authority rather than on horizontal relations of cooperation and mutual trust [31]. China's Protestants are fragmented into underground vs aboveground churches and into competing sectarian groups [32]. How much and what kind of trust do Protestant groups generate? Alesina and Ferrara [33] found that belonging to a minority, which is often a group that has historically been discriminated against, is associated with having low trust. Will this be the case for Protestants in China that they, too, like Catholics, end up trusting primarily their family members and personal guanxi networks [34]? This paper is an attempt to provide an answer to the effect of Protestant Christianity on trust and trustworthiness, both within and between believers and others.

\section{Research Method and Profile of Respondents}

The data was collected through in-depth interviews. Our researchers ${ }^{1}$ completed $43^{2}$ usable face-to-face interviews with a diverse group of Chinese Christian entrepreneurs in China from 2006 to 2007. The respondents were selected from various cities in China including Beijing, Changsha, Chengdu, Chongqing, Hangzhou, Nanjing, Shanghai, Shenzhen, Wenzhou and Wuhan. The respondents, nine of them women, consist mainly of business owners and a few CEOs, high-ranking managers, and one business attorney. All of them, except two managers, were from private businesses, most of whom started their initiatives in the mid- and late-1990s. The size of their business varies, with the largest factory containing around 5000 to 6000 workers, while the smallest has three. In terms of length of religious affiliation, half of the respondents were baptized between 1996 and 2006. Most of the rest were raised in Christian families but became serious about their faith when they were adults. Many of them were converted or reintroduced to their faith through friends, including business partners and clients, or family members.

The interviews were semi-structured and open-ended, including questions about conversion and religious participation experiences, business and managerial practices (Appendix A). Such questions are either private or very sensitive in nature. This is more so in the context of China, as religious activities are only permitted within a church compound and are under tight control. As is to be expected, some people did not wish to answer questions that they deemed sensitive or personal or, in some cases, provided an answer but refused to explain why. There is a discrepancy or gap in some numbers as we were unable to collect a complete set of answers for all questions.

Trust is an abstract concept that might not carry the same meaning in different contexts. In this paper, we defined trust as having confidence in people's good will towards us and that they intend to keep their word and reliably accomplish the tasks we assign them.

\section{Trust in Employees}

\subsection{The Weight of "Faith" in Hiring Decisions}

In responding to a question about their criteria of hiring, among the 32 who responded, only one mentioned that the other's faith is crucial and that he would only hire Christians. His decision was not based on his beliefs but instead upon the nature of his business. He owns a media company that

\footnotetext{
Thanks to Dr. Li Xiangping and his research assistants in collecting data.

$2 \mathrm{Li}$ and his research assistants have interviewed 45 Christian entrepreneurs. However, due to the incomplete data, we have only managed to analyze 43 interviews.
} 
produces Christian books and CDs. On the other hand, there was also one who indicated that she did not want to hire Christians because "they expect more from a Christian boss, that you will be more loving and forgiving if they make mistakes."

In between these two answers that are on the extreme end of the continuum, there are various options of faith/hiring considerations. Eight respondents mentioned that the other's faith does not carry weight in their hiring decision. For some, the idea of hiring a Christian was impractical as they rarely came across Christians in their business relationships. For others, it was irrelevant. As described by Mr. W., "My only concern is to find the right person for the right job. If not, we are not a good steward. Good Christians do not necessary [sic] mean good employees." Two respondents mentioned that they preferred Christians and believers of other religions. For them, religion, as long as it is one of the major religions that are recognized by the Chinese government, helps make a good person.

The majority of our respondents (20) mentioned that the other's faith was an important factor, although not the only one, in their hiring decision. The rationales offered included: (1) Christians are generally more honest, less likely to cheat an employer and they work harder; (2) common ground in faith makes employer-employee communication easier; (3) sharing the same faith will help build a stronger work team and reduce turnover rate. However, the other's faith was not the most decisive factor in their hiring decision. As mentioned by Mr. F from Shanghai, "I always feel that Christians are generally better persons; the more one learns about Christianity, the more he wants to avoid things that go against his conscience. But still our first concern in doing business is to gain profit. We need to find people that are competent. The best choice will be a competent Christian." For Mr. F and people like him, an employee's skills and track record are equally, if not more, important than his religiosity. Thus, if candidates have similar skills or the job does not require specific skills, they prefer Christians. As described by Mr. Z from Hangzhou, "When two resumes with similar background are placed on my desk but one is Christian and one is not, of course I will choose Christian. But if two men appear before me, I need to find out more about their abilities and faith (before deciding which one to choose)." This shows that trust is a function of two things: competence and religiosity, which is assumed to be related to character. Without competence, religiosity by itself is insufficient to induce trust. Ms. Y's comment captures well the wish of most Christian entrepreneurs, "If I find someone that is competent, and that he is also a real Christian, honestly, I will be elated that I can't sleep at night. Surely the first thing is to give thanks to God!" Indeed, it requires a miracle to find someone in the job markets in China who fulfills the stated requirement of competency and unstated expectation of religiosity. To meet the needs, most worked the other way around. They hired people based on abilities but attempted to evangelize him or her afterwards. Our study shows that 29 respondents have shared faith openly with their employees. This is apparently one way to reach the goal of having capable employees who shared their values.

\subsection{The Weight of "Faith" in Employee Treatment}

After hiring someone, when strangers become familiar persons, whom would Christian employers trust more? Will employees' religiosity play a role in this? Among our respondents, eight mentioned that they did not trust or treat Christian employees differently. They followed the company's rules in relating to employees and expected the same from them. As mentioned by Mr. D, owner of a Wenzhou-based valve business that hired more than 500 workers, "Sometimes when a Christian violated certain rules and was imposed a fine, he would argue, 'We are Christians and God is merciful. How can you treat me like this?' I said, 'faith is faith and work is work. Every company has its rules and we have to impose that consistently.'" Mr. B installed a device on each employee's computer so that he can track their moves. "That was installed on every computer, including those used by the best workers or Christians. I distribute jobs according to their capability and responsibility. I don't consider their religiosity."

On the other hand, seven respondents mentioned that they have more trust in Christian employees. This did not, however, necessarily mean that Christians enjoyed more privilege than their non-Christian 
colleagues. Quite the contrary, many mentioned that they trusted Christians' integrity more and expected them to be role models for others. The comment of Mr. L, who hired 30 workers, illustrated this: "My business has not been stable. When things gone tough many workers disappeared. During those times I relied on my Christian workers. They were my 'fire brigade' that filled in the gap. I trust them a lot but I do not promote them to be leaders. They can be too honest sometimes and not canny enough. I also do not want people to think that I am biased." Or as mentioned by Mr. G, "When I hired Christians I warned them that this is not a comfortable place to work at. Some of them assumed that a Christian boss would take special care of them. No. We are all working for God, we need to have better performance and endure more hardship. You do what others don't want to do, but you don't play bad tricks as others do." Quite counterintuitively, Christians do not seem to enjoy favorable treatment under Christian bosses. The reasons might be, first, most people want to be seen as fair in dealing with their employees, a strategy that will help them to create a stable working environment and to retain their workers. Also, by intentionally avoiding to show preference, Christian bosses have demonstrated that they are trustworthy and increased credits in the "trust accounts" they have with non-Christians, who make up the majority of their employees.

\section{Trust in Clients and Suppliers}

Unlike employees, clients can be temporary contacts, but if things go well, they become long-time business partners. In dealing with clients, how do Christian entrepreneurs decide who can be trusted, i.e. that the other parties will pay money on time? Or, under what conditions would Christian entrepreneurs agree to trade goods on credit? Will their faith or that of the clients' play any role in this decision?

In our study, 27 respondents mentioned that they trusted Christian clients more and were more willing to do business with them for three reasons: (1) mentally, they felt more at ease dealing with Christians because of the shared faith and values; (2) emotionally, they felt a natural sense of closeness, as illustrated in the story of Mr. A: "I've been dealing with a client for more than two years. Things went well and we have a good impression on each other. Last Christmas I bumped into him at a church where he was serving as an usher at the church's front door. It was such a great surprise to know that we were both Christians! Now looking back, I should say it is always good to do business with Christians. I have a natural good feeling toward them"; (3) the cost of doing business with Christians is also lower because of less money being spent on dinner parties, kickbacks, and expensive gifts.

Another nine respondents mentioned that they trusted religious people, regardless of what that religion is, more than the non-religious. They understand religions, despite their different pursuits and doctrines, to govern their adherents' behaviors and encourage integrity. They think this makes religious people more trustworthy.

Nevertheless, although a great number of Christian entrepreneurs claimed to have more trust in Christians, their trust is not without reservation. In fact, the level of their trust is dependent on the perceived level of the other's religiosity. This is evidenced by the fact that 15 of the 27 respondents mentioned their misgivings in doing business with Christians. The key problem is the difficulty to decide whether the other is a "true" Christian. As someone said, "The church's door is widely opened, anybody can enter and claim to be a Christian." They have confidence that a true believer, one that is sincere in faith, would be a person of integrity. But there are so-called Christians who do not behave as they claim or, worse, are "fake" Christians who use faith as a cover to lure others into a scam. About half of them have personally experienced, or known someone who has suffered, financial loss, either through doing business or daily interaction with someone who claimed to be Christian. At least two have been trapped into a scam by clients whom they thought were Christians. This explains why a significant number of Christian entrepreneurs said they did not invest trust in someone solely by the fact that the other claimed to be a Christian. It is surely a big plus in the "trust account" if the other happens to be a true believer. Sharing the same faith is helpful in creating basic trust and a positive impression, especially for strangers. Yet in building long-term trust, most people would also rely on 
the combined knowledge of the other's character and reputation. Such knowledge does not come by easily and they have to utilize their own faith in making good decisions. As illustrated by Ms. Q, "Whenever a business opportunity arises, even if the other party is a Christian, I will try my best to have a comprehensive knowledge of him before I decide. But it takes a lot of effort to really know a person. Besides doing background check I pray a lot. I ask God, if this is your will, let us proceed smoothly. If not, please close the door."

There were also several Christian entrepreneurs who said that the other's faith was not a consideration in building relationships with clients, as they merely "follow the rules of market."

It should be noted that although many of our interviewees mentioned that they trusted Christians more, they did not mean that they do not trust people of other faiths or the non-religious. It was frequently mentioned that "many non-Christians are good persons too," "non-Christians' behaviors do not necessarily worse than Christians," or "some non-Christians have better characters than Christians," etc. When asked if they would avoid building trusting relationships with people of other faiths or no faith, all responded that that would be unrealistic and unnecessary. As mentioned by Mr. J, "There are hard rules and norms in doing business. There are objective indicators that you can use to evaluate your clients. Whether you truly trust a person or not is another matter. If you don't trust him that much, you can choose not to have further contact with him outside of business."

\section{Earning Trust from Employees and Clients}

\subsection{Employees}

We have found in our study 23 respondents who have, to varying degrees, integrated faith with people management. That is to say, Christian values have motivated them to stipulate worker-friendly policies, which can be very rare among Chinese businesses, such as having a day off on Sunday, providing full insurance coverage, paying on time, paying overtime wages, etc. Worker exploitation is a serious issue in China today; labor control is usually punishment-oriented and in many situations workers, especially migrant workers, are not paid on time or at all. It is thus interesting to find out the reasons behind such favorable efforts and their actual influence, if any, in winning employees' trust.

We have found four main reasons, some spiritual while others are more practical, for such faith/business integration: (1) they thought such policies would motivate people in a positive way and that they could make up for the limitation of hard rules, which can only control people's outward performances; (2) they wanted to create a more humanistic working environment that could help keep their employees; (3) they perceived their business as a "marketplace ministry"-a platform for them to serve God and others in the workplace; (4) it is a biblical command that they treat their employees kindly.

Through the following three cases, we will illustrate different ways of integrating faith with people management and describe the impacts that accompany them. First, Mr. S owns a media company in Chengdu. Unlike many who want their business to grow big quickly, he has purposely kept the company size lean because he wants to build a corporate culture centered on people rather than profit. For him, building a strong team is the most important thing and he sees himself as a shepherd who looks after the flocks. The metaphor is clearly inspired by the biblical image of Jesus and his followers. Mr. S said, "I find time to talk to each of my employees individually once in a while. I ask them about their work, their family and kids, financial situation and etc. I said I am not talking to you as your boss but your brother and friend. They did not believe me initially, but now they are willing to share many things with me."

The second example is Mr. K from Hangzhou, who owns a construction company that hired five to six thousand workers. He received several awards and was interviewed by national TV reporters because of the migrant workers' schools that he established, the only ones of their kind in the country. Asking why he started the schools, Mr. K said, 
I value my employees, especially those migrant workers. Many bosses do not treat them as humans. But because of my faith I treat them sincerely. When I first hired them, their quality was very low. They abused the dorm's furniture and we found human excrement everywhere. They were very hostile against us. I wanted to change the situation and I wanted to build a platform that we can communicate. So I started a school for them in 1999. We have lessons on personal security, cultural quality, legal knowledge, positive attitudes and so on. I asked them to tell us their expectations and we improved our cafeteria and dorms. I also set up a poverty action fund and that has helped them significantly. Anybody that has difficulties in family or children education can apply and we provide at least 2000 each according to their needs ... Several years ago I overheard someone told a reporter, "We can find other factories that offer $4.2 \mathrm{RMB}$ per hour. But we rather work here, $4 \mathrm{RMB}$ an hour, why? Our hearts are at ease working here."

The third example is Mr. and Mrs. C, who own one of the largest and leading wooden comb manufacturing businesses in China. Their business spread to more than 31 cities in China and has more than 1000 employees and 600 to 700 franchisees in 2007. They have always emphasized the value of honesty in dealing with workers since the beginning of their business. However, after both becoming Christians in 2007 , they have determined to go extra miles, i.e. to grant equity to every employee after the company was listed as a publicly held company in Hong Kong in 2009. In his words:

I've always wanted to deliver stock option to my employees, but that was only for my core managers. Workers were never in my consideration. But after being a Christian I realized that people who needed my care most are not those high ranking managers but my front-line-workers. I then decided to deliver stock option to all employees including workers. It means I have offered more than 70 million RMB to them and in doing so diluted about $10 \%$ of my stock. My hope is to see my front-line-workers being lifted out of poverty a few years down the road. Such an idea had never been in my thought before, I have been changed (by my new faith) now.

These examples have demonstrated how Christian entrepreneurs, by applying their values to their work, have, sometimes unwittingly, created trust in their corporation. The main point underlying these stories is that religious values have helped Christian entrepreneurs to create structures and systems that eliminate barriers between employers and employee, decrease management costs in the long run by retaining workers, and eventually create organizational trust dividends.

\subsection{Clients}

In dealing with clients and vendors, we have found that 23 people viewed integrity and competency as the number one factor in earning the other's trust. This is similar to the standards, as discussed in the previous paragraphs, that they expect to see in others before placing their trust. They typically explained integrity in the following ways:

(1) To keep one's words. This is a difficult practice in a low-trust yet fast-moving society like China, where people are less willing to make long-term commitments, knowing that it is more practical in an uncertain situation to make only shallow commitments so that one can change when the situation demands. As mentioned by Mr. K:

I always take the initiative to call my suppliers whenever I have money to pay them. I don't want to behave like people that keep money in their own pockets. They don't plan to run away or to cheat, but just don't want to pay. Maybe they feel good to keep the money. But I feel relief after clearing my debts. One of my suppliers said that he can't understand why there is people like me in this world. 
K's case might be uncommon but he is surely not the only one who wanted to keep his words. Ms. H from Shanghai said,

In my view trust is like saving money; every time you say or promise something, you need to fulfill that. If so, people will in their heart add one credit to your "account". But if you don't, even just for once, they will deduct credit from your 'account', not one credit but all. That's why I am very careful in dealing with others. It is very hard to create trust, you accumulate it one credit by one credit, but it is very easy to destroy trust, any single event and that's it.

(2) To be true to facts. Ms. L first became involved in the insurance business when she was 19 years old. She met her first client after many cold meetings and that client stayed with her until today. One belief that she has held on to is that customers deserve to know all the facts about their purchase. Instead of exaggerating advantages and downplaying weaknesses, $\mathrm{L}$ wanted to be honest about her product. She said, "There were many people who wanted to buy a retirement fund from me. I instead suggested them to buy welfare fund, although I don't sell it, because that will bring higher interests twenty years down the road. I just told the truth. I once heard a client of mine said to another person about me, "This girl is really honest.'" It turned out that because of her transparency, many clients sought her out whenever they needed to buy insurance and recommended her to their friends. Her company grew to become one of the largest in Shanghai. When our researchers met her in 2007, she had already developed more than 1000 clients individually and 10,000 collectively with her partners.

(3) To offer a reasonable price and to preserve the quality of product. As mentioned by the cotton-owner Mdm. W, "If you want to build long-term clients, you need to produce real and quality goods, not pirated ones. For example, if I produce second grade cotton I don't claim that it is first grade. Also, I don't cheat on the quantity. I'd rather earn less by investing more money on maintenance to make sure that the quality of my product is up to the standard." Mr. L's comment is more straightforward: "If you can't prove to others that you are capable in producing good products, then forget about your character. You can't say, oh, I believe in God and people should trust me."

To the extent that integrity is about being honest with others, it can surely help in building positive business relationships. Nevertheless, there is another side of the coin about having integrity. To be honest with God, one has to shun practices that are common to Chinese businesspeople but are against their faith in building smooth relationships with local bureaucrats and clients. These include bribing, taking kickbacks, cheating on tax returns, offering sexual entertainment, etc. In practice that means, as mentioned by Mr. R, “I don't smoke, I don't go to karaoke. I treat my client dinner but sorry, I don't drink. If you want more entertainment after dinner, I can pay but I don't join. I stay till 12 a.m. and say I have to report to my wife and you enjoy yourself."

In China's transition economy, it is common that contracts are decided by connections and bribes. The deviant type of guanxi is widespread and seen by many as the uniqueness of the Chinese form of networking. For people like Mr. R, they are obviously putting themselves at a competitive disadvantage to more ruthless rivals. It was no surprise that five of our respondents were forced to change their business plans because of conflicts with their faith. Mr. F, who owns a tourist agency in Shenzhen, changed to online business to avoid taking and giving kickbacks from clients and service providers such as hotels and restaurants. Mr. H owns a bookstore in Wuhan. He used to carry pirated books and CDs but after being a Christian, he decided to stop the lucrative business. Mr. T from Changsha has to shift his business focus from lightning protection engineering, which is very profitable but also deeply corrupt, to other business projects.

That said, in some situations, such as Ms. L's, their seemingly unfavorable practices could help them to win trust from serious clients instead. As echoed by Mr. K, "Ultimately it is about your product and your character. You may eat and drink and bribe, but in the long run it is about whether you and your product can be trusted." Mr. W's comment summarizes the main point underlying this section: 
I think people trusted me even before I became a Christian. But it was a different type of trust. They trusted me because I had money. I treated them to expensive seafood at high end restaurants. I have strong technical abilities and people trusted my skill. But that kind of trust was merely an act or a game. If I get into troubles would they help? The trust that I have gained now is very different from before. It is a trust that is based on my character. Now I feel that they truly trust me.

\section{What Aspects of Religion Lead to Trust?}

We have examined how the religiosity of others, i.e., employees and clients, affects Christian entrepreneurs' trust in them. We have also discussed how Christian entrepreneurs' own religiosity, exemplified through being a person of integrity, affects others' trust in them. The next question will be, what aspects of religion lead to trust? We have found many aspects of religion that lead to trust, but in the following paragraphs, we will focus on the three most important factors in inducing trust and illustrate them with examples.

The first factor is their belief that God is in control of every situation. The story of Mr. P from Chengdu illustrates this. "From Christian's point of view, all men are not trustable. But because I believe that God is in control, I dare to trust. Even if I suffer loss, I believe God allows it to happen." The way he treated beggars was an interesting illustration of his attitudinal change from distrust to trust.

There are many beggars out there but maybe they are cheater. Some look very pathetic, shivering with running sore on their bodies. I want to give them money but I used to feel very uncomfortable after giving because I wasn't sure if I were cheated like a fool. That was my struggle. Now I will just give and take it as God's test for my love for others. I can't be responsible for that person's behavior but I am responsible to God for my behavior.

The second factor, which is related to the first, is their belief that truth will ultimately prevail even if that means suffering a loss temporarily. This is exemplified through Mr. S's story. He directed a technology lab based in Beijing. Leading a group of smart engineers, he gave them freedom to choose their working hours and projects and trusted them fully. Three years ago, his best engineer left because of a three-times-higher salary that his rival offered. Mr. S said:

I said blessing to his decision. But three years later he returned. I believe my laissez-faire management style works; the good ones will stay, and even if they leave they will return. I have faith in God, and that helps me to have faith in others and in the future. I believe truth will win and honesty will reap good fruits eventually, even if you have suffered loss. I know there is a person above us. In my job, for example, I work very hard, but maybe nobody appreciates me, but God does. In fact, God's recognition is more important than everyone else.

The third factor is because they have experienced a change in their understanding and attitude towards themselves and others. Mr. C was the general manager of a toy factory based in Shenzhen. He said:

What I did before [being a Christian] was assigning two persons to accomplish a task separately. I'd let them fight and compete and they ended up defeated and distrusted everybody ... that was a management style too, divide and rule. But now I gave up on this method. I told them that I am a Christian and will do things righteously. No more little tricks. We set up quality control department and define everybody's jobs clear and open. I think we have cultivated a frank and clean attitude.

Along the same line, Mr. N from Nanjing described the different attitudes he has while he was a believer in Fortune God and after becoming a Christian. The former was "keeping everything, good or 
bad, to myself and never share," an attitude that demonstrated his distrust for others, while the latter was "having more love and gratitude and more willing to share with others."

\section{Conclusions}

Through a qualitative study of 43 Chinese Protestant entrepreneurs, we have attempted to shed light on three issues regarding trust and religion in China. First, our study shows that the majority of our respondents were more willing to be trustworthy and to trust others after becoming Christians. They were more motivated to be a person who is worthy of trust and, also, to anticipate that the other would respond to their trust, to the extent that they believe in a morally concerned God who is in control of everything.

Second, this paper joins other studies in demonstrating a stronger in-group trust; that a majority of our respondents trust people who share their faith and moral understanding more than others. But this does not mean that their trust is limited only to Christians. In fact, many of them base their trust on two main factors: competence and religiosity. Without competence, religiosity by itself is insufficient to induce trust. Also, the in-group trust that they cultivate is not absolute but depends on the perceived religiosity of the others. More than half of our respondents who said they have more trust in Christians indicated that the amount of trust they invest in the other Christian increases with the other's religiosity. Religiosity is effectively used by a majority of them as a category to guide their decision-making in matters such as hiring. This is not surprising in the Chinese context, where the emphasis in cultural tradition is less on identity and more on praxis.

Third, in some cases, the in-group trust is extended to people of other faiths as well. Despite the difference in doctrine and rituals, some of our respondents understand religion, as long as it is a major one, to lead to better moral behaviors. To the extent that one holds this view, religious persons are perceived as more trustworthy than the non-religious. In a society dominated by the official ideology of atheism, believers of different religions may find solidarity in the sea of irreligion.

Based on our limited data, what can be said so far is that for the majority of our Christian respondents, religion is helpful in stimulating and maintaining trust in and from others. It has, to various degrees, oriented our respondents' daily business practices in a very secular society such as China toward an ethical direction. Overall, instead of shying away, most respondents are keen to express and integrate faith with their business. Our results suggest that Christianity can be one possible source of a new business morality in China. Indeed, the kind of business practices and life witnesses of Christians may have served as a factor for the rapid increase of Christians in China today.

Author Contributions: Joy Tong contributed to the analysis of data and writing of the paper. Fenggang Yang contributed to the design of the research.

Conflicts of Interest: The authors declare no conflict of interest.

\section{Appendix A}

We used semi-structured interviews with guiding questions about their beliefs, practices, and job/business history and experiences. The interview included these questions:

(1) When did you become a Christian? When were you baptized?

(2) Do you have family? Are they believers?

(3) Tell me your education background?

(4) What was your job experience?

(5) When and why did you decide to enter the present business?

(6) Do you see any conflict between your business (past and present) and faith?

(7) Is your faith helpful or not for doing your job (past and present)? In what ways?

(8) If you were not a religious believer, would you do things differently in your business?

(9) Before and after your conversion, how did you deal with your spouse, parents, and children? 
(10) Before and after your conversion, how did you deal with people at work: with employees, with customers and suppliers, with business partners etc.

(11) In these relationships, how do you decide in whom can be trusted or not be trusted? Can you provide examples of events, incidents, and issues that have effected your trust in various people?

(12) Does your faith affect your trust in your business partners, clients, and employees? Does your faith affect your hiring decision? Explain how and provide examples to illustrate it.

(13) In general, who do you trust most? Family members, people from the same village, fellow believers, believers of other religions, previous classmates?

(14) Does your faith affect your trust in people in general? How so?

(15) What kind of religious activities do you participate in? How often? Any change over time?

(16) Please describe the god(s) you believe in. How much are they (is he) concerned about moral issues? How are the gods rewarding good behavior or punishing immoral behavior?

(17) In your opinion, what are the ethical norms that your faith requires you to follow?

\section{References}

1. Benjamin Kang Lim, and Ben Blanchard. "Xi Jinping hopes traditional faiths can fill moral void in China." Available online: http:/ / www.reuters.com/article/us-china-politics-vacuum-idUSBRE98S0GS20130929 (accessed on 15 December 2016).

2. "Trust Crisis." Available online: http://old.newschinamag.com/magazine/trust-crisis (accessed on 15 December 2016).

3. "Trust among Chinese drops to record low." Available online: http://www.chinadaily.com.cn/china/201302/18/content_16230755.htm (accessed on 15 December 2016).

4. Robert Putnam. Making Democracy Work: Civic Traditions in Modern Italy. Princeton: Princeton University Press, 1993.

5. Francis Fukuyama. Trust: The Social Virtues and the Creation of Prosperity. New York: Free Press, 1996.

6. Sioerd Beugelsdijk, Henri L. F. de Groot, and Anton B. T. M. van Schaik. "Trust and Economic Growth: A Robustness Analysis." Oxford Economic Papers 56 (2004): 118-34. [CrossRef]

7. Stephen Knack, and Philip Keefer. "Does Social Capital Have an Economic Payoff? A Cross-Country Investigation." Quarterly Journal of Economics 112 (1997): 1251-88. [CrossRef]

8. Kenneth Arrow. "Gifts and Exchanges." Philosophy and Public Affairs 1 (1972): 343-62.

9. Daniel Bays. "Christian Protestant Christianity Today." The China Quarterly 174 (2003): 488-504. [CrossRef]

10. Xiao Zhao. “A Market Economy with Church and a Market Economy without Church (有教堂的市场经济与 无教堂的市场经济)." Esquire, 6 January 2006.

11. Carol L. Hamrin. "China Protestants: A Mustard Seed for Moral Renewal? " Available online: http: //www.aei.org/publication/chinas-protestants (accessed on 15 December 2016).

12. Joy. K. C. Tong. Overseas Chinese Christian Entrepreneurs in Modern China: A Case Study of the Influence of Christian Ethics on Business Life. London: Anthem Press, 2012.

13. Qunyong Wang, and Xinyu Lin. "Does Religious Beliefs Affect Economic Growth? Evidence from Provincial-Level Panel Data in China." China Economic Review 31 (2014): 277-87. [CrossRef]

14. Cunfu Chen, and Tianhai Huang. "The Emergence of a New Type of Christians in China Today." Review of Religious Research 46 (2004): 183-200.

15. Nanlai Cao. "Christian Entrepreneurs and the Post-Mao State: An Ethnographic Account of Church-State Relations in China's Economic Transition." Sociology of Religion 68 (2007): 45-66. [CrossRef]

16. Fenggang Yang. "The Chinese Protestant Ethic during the Market Transition in China." In Chinese Culture and Christianity. Edited by Xiyi Yao. Hong Kong: CGST Press, 2007.

17. Xiangping Li, and Fenggang Yang. "Christian Ethics and the Construction of Social Trust-The Study of Contemporary Chinese Christian Business (基督教伦理与社会信任的关系建构).” Available online: http://www.mzb.com.cn/html/report/142631-1.htm (accessed on 15 December 2016).

18. "Restaurant confronts Chinese moral crisis with free food." Available online: http:/ /www.telegraph.co.uk/ news/worldnews/asia/china/10480084/Restaurant-confronts-Chinas-moral-crisis-with-free-food.html (accessed on 15 December 2016). 
19. Emile Durkheim. The Elementary Forms of the Religious Life. London: Allen and Unwin, 1976.

20. Max Weber. "The Protestant Sects and the Spirit of Capitalism." In From Max Weber: Essays in Sociology. Edited by Hans Heinrich Gerth and Charles Wright Mills. New York: Oxford University Press, 1958, pp. 302-22.

21. Rodney Stark. "Gods, Rituals, and the Moral Order." Journal for the Scientific Study of Religion 40 (2001): 619-36. [CrossRef]

22. Niclas Berggren, and Christian Bjørnskov. "Does Religiosity Promote or Discourage Social Trust? Evidence from Cross-Country and Cross-State Comparisons." Available online: http:/ / ssrn.com/abstract=1478445 (accessed on 12 December 2016).

23. Steven D. Levitt, and John A. List. "What Do Laboratory Experiments Measuring Social Preferences Reveal About the Real World? " Journal of Economic Perspectives 21 (2007): 153-74. [CrossRef]

24. Robert Putnam. Bowling Alone. New York: Simon and Schuster, 2000.

25. Michelle P. Claibourn, and Paul S. Martin. “Trusting and Joining? An Empirical Test of the Reciprocal Nature of Social Capital." Political Behavior 22 (2000): 267-91. [CrossRef]

26. Eric M. Uslaner. The Moral Foundations of Trust. Cambridge: Cambridge University Press, 2002.

27. Laurence R. Iannaccone. “Sacrifice and Stigma: Reducing Free-Riding in Cults, Communes, and Other Collectives." Journal of Political Economy 100 (1992): 271-91. [CrossRef]

28. Christian Smith, Michael Emerson, Sally Gallagher, Paul Kennedy, and David Sikkink. American Evangelicalism: Embattled and Thriving. Chicago: University of Chicago Press, 1998.

29. Max Weber. The Religion of China: Confucianism and Taoism. New York: Macmillan, 1951.

30. Gordon Redding. The Spirit of Chinese Capitalism. Berlin and New York: Walter de Greuter, 1990.

31. Richard Madsen. China's Catholics: Tragedy and Hope in an Emerging Civil Society. Berkeley: University of California Press, 1998.

32. Ryan Dunch. "Protestant Christianity in China Today: Fragile, Fragmented, Flourishing." In China and Christianity: Burdened Past, Hopeful Future. Edited by Stephen Uhalley Jr. and Xiaoxin Wu. Armonk: M.E. Sharpe, 2001, pp. 195-216.

33. Alberto Alesina, and Eliana La Ferrara. “Who Trusts Others? ” Journal of Public Economics 85 (2002): $207-34$. [CrossRef]

34. Shining Gao, and Fenggang Yang. "Religious Faith and the Market Economy: A Survey on Faith and Trust of Catholic Entrepreneurs in China." In Money as God: The Monetization of the Market and its Impact on Religion, Politics, Law, and Ethics. Edited by Jürgen von Hagen and Michael Welker. Cambridge: Cambridge University Press, 2014, pp. 339-61. 